Tropical Journal of Pharmaceutical Research July 2020; 19 (7): 1535-1540

ISSN: $1596-5996$ (print); 1596-9827 (electronic)

(C) Pharmacotherapy Group, Faculty of Pharmacy, University of Benin, Benin City, 300001 Nigeria.

Review Article

http://dx.doi.org/10.4314/tjpr.v19i7.28

\title{
Development of memantine as a drug for Alzheimer's disease: A review of preclinical and clinical studies
}

\author{
Yusuf S Althobaiti \\ Taif University, College of Pharmacy, Department of Pharmacology and Toxicology, Taif, Saudi Arabia, Taif University, \\ Addiction and Neuroscience Research Unit, Taif, Saudi Arabia \\ *For correspondence: Email: ys.althobaiti@tu.edu.sa; Tel: +966-545736200 \\ Sent for review: 18 March 2020 \\ Revised accepted: 20 June 2020
}

\begin{abstract}
Excitotoxicity contributes to neuronal cell death due to overstimulation of N-methyl-D-aspartate (NMDA) receptors by glutamate, which plays a significant role in the development and progression of Alzheimer's disease (AD) and other neurodegenerative disorders. Studies have been conducted to identify a well-tolerated and selective NMDA receptor blocker in an effort to alleviate neurodegeneration. Memantine has been found to induce a distinct low-affinity NMDA receptor blockade in both preclinical and clinical studies Therefore, FDA approved this drug as a well-tolerated noncompetitive NMDA receptor blocker for treating moderate to severe cases of $A D$. Further, memantine showed neuroprotective effects in preclinical studies by selectively blocking excessive NMDA receptor activation. Altogether, this novel drug is well-tolerated and effective for treating moderate to severe $A D$ in various clinical studies. This paper is a review of preclinical and clinical studies on the drug development process of memantine.
\end{abstract}

Keywords: Memantine, Excitotoxicity, N-methyl-D-aspartate, Glutamate, Alzheimer's disease, neurodegeneration

\begin{abstract}
This is an Open Access article that uses a fund-ing model which does not charge readers or their institutions for access and distributed under the terms of the Creative Commons Attribution License (http://creativecommons.org/licenses/by/4.0) and the Budapest Open Access Initiative (http://www.budapestopenaccessinitiative.org/read), which permit unrestricted use, distribution, and reproduction in any medium, provided the original work is properly credited.

Tropical Journal of Pharmaceutical Research is indexed by Science Citation Index (SciSearch), Scopus, International Pharmaceutical Abstract, Chemical Abstracts, Embase, Index Copernicus, EBSCO, African Index Medicus, JournalSeek, Journal Citation Reports/Science Edition, Directory of Open Access Journals (DOAJ), African Journal Online, Bioline International, Open-J-Gate and Pharmacy Abstracts
\end{abstract}

\section{INTRODUCTION}

The number of patients with Alzheimer's disease (AD) has been estimated to reach more than 13.5 millions by 2050 in the United States [1]. AD is a progressive neurodegenerative disease in which the functional and cognitive capabilities significantly deteriorate as the disease progresses [2]. Excitotoxicity contributes to neuronal cell death, which plays a significant role in the development and progression of $A D$ and other neurodegenerative disorders. Excitotoxic neuronal cell death and injury occur primarily due to the overstimulation of $\mathrm{N}$-methyl-D-aspartate (NMDA) receptors by glutamate, which is the primary excitatory amino acid transmitter in the mammalian brain [3]. Studies have been conducted to identify selective NMDA receptor blockers as neuroprotective agents to treat neurodegenerative disorders. Unfortunately, most NMDA receptor antagonists failed due to disruption of the normal physiological function of NMDA receptors and the subsequent side effects [4]. However, memantine induced a distinct lowaffinity NMDA receptor blockade in both preclinical and clinical studies. Therefore, 
memantine was approved by FDA as a welltolerated noncompetitive NMDA receptor blocker for treating moderate to severe $A D$ [5]. The aim of this report was to review memantine drug development in preclinical and clinical studies.

\section{NMDA receptors' role in neurodegenerative diseases}

NMDA receptors are ionotropic glutamate receptors that are highly permeable to calcium [6]. Chronic activation of NMDA receptors leads to calcium influx and subsequent free radical formation that promotes cell death [3]. Studies have indicated that several neurodegenerative diseases, such as AD, Huntington's disease, and Parkinson's disease, are characterized by excessive glutamatergic activation of NMDA receptors causing neuronal cell injury and death [7]. Several studies have been undertaken to identify a well-tolerated selective NMDA receptor blocker in an effort to alleviate neurodegeneration in such diseases [8]. Unfortunately, most of the selective NMDA blockers failed in clinical trials due to disruption of normal glutamatergic functions and the resulting severe side effects [4]. Surprisingly, memantine, which was believed to be an antiinfluenza agent, exhibited selective disruption of NMDA-mediated excitotoxic cell death at a welltolerated clinical dose [9].

\section{Discovery of memantine}

Memantine is a polycyclic cage compound that was first synthesized in 1968 as a derivative of amantadine (Figure 1), which was believed to be an anti-influenza compound [10]. It was suggested that amantadine might block the ion channel of the influenza virus by forming a hydrogen bond with a histidine residue in the $\mathrm{M} 2$ transmembrane protein [11]. Upon the application of amantadine and memantine as treatment for influenza, the compounds exhibited, by serendipity, clinical efficacy in Parkinson's disease patients [12].

Consequently, investigators believed that memantine and amantadine may have some effect on the dopaminergic or cholinergic systems [13,14]. This belief was not opposed until the early 1990s when memantine was found to be devoid of dopaminergic or anticholinergic activities but was instead found to be a selective antagonist of NMDA receptors [15]. Memantine receptor blockade occurs during prolonged NMDA receptor activation, as observed in excitotoxicity, which confers memantine with a unique advantage over other NMDA receptor blockers [16]. This type of NMDA receptor blockade allows for the normal physiological functioning of NMDA receptors and disrupts neuronal toxicity as a result of NMDA receptor overstimulation [17].

As a result, memantine is favored over other NMDA receptor antagonists for its tolerability and safety and an improved side effects profile [17]. It is noteworthy that the mechanism by which memantine interacts with NMDA receptors is not fully understood. However, it has been suggested that the ammonium group of memantine might interact with the side chain of the GluN1 subunit of the NMDA receptor and block its action [18].

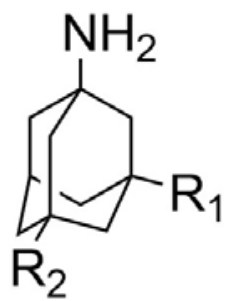

Figure 1: Chemical structures of amantadine $\left(R_{1}\right.$ $\left.=\mathrm{H}, \mathrm{R}_{2}=\mathrm{H}\right)$ and memantine $\left(\mathrm{R}_{1}=\mathrm{CH}_{3}, \mathrm{R}_{2}=\right.$ $\mathrm{CH}_{3}$ )

\section{In vitro studies}

\section{Memantine NMDA receptor antagonism assay}

Rat retinal neurons have been studied in vitro to evaluate the functional activity of NMDA receptors [19]. The use of rat retinal ganglionic neurons in evaluating the pharmacological effect of different compounds on NMDA receptors is well established [20]. Studies have been conducted to investigate the effect of memantine on the N-methyl-D-aspartate-evoked current in rat retinal neuron cell culture [21], and memantine was found to disrupt this current with a $50 \%$ inhibition concentration of approximately 1 uM [22].

\section{Memantine inhibition of NMDA-induced calcium influx}

In a study that utilized digital calcium imaging technology, memantine strongly inhibited excessive calcium influx simulated by a high concentration of N-methyl-D-aspartate. However, memantine allowed a low level of calcium influx similar to that evoked by a low concentration of $\mathrm{N}$-methyl-D-aspartate. This observation was the basis of the hypothesis that memantine inhibits only the overstimulation of NMDA receptors as in excitotoxicity and allows for the normal physiological functioning of NMDA receptors. As 
a result, memantine exhibits a unique advantage over other NMDA receptor antagonists [21].

\section{Memantine disrupted NMDA receptor- mediated neurotoxicity}

In this type of neurotoxicity assay, retinal or cortical neuronal cell culture is exposed to glutamate in the presence of a high concentration of calcium and low concentration of magnesium [23]. As a result, neurotoxic cell injury is specifically mediated through NMDA receptors. It has been demonstrated that the neurotoxic effect mediated by NMDA receptors is ameliorated by memantine in both cortical neurons and rat retinal ganglion cell culture $[22,24]$. Likewise, memantine strongly blocked the neurotoxic effects of glutamate in cortical neuron cell culture [25].

\section{In vivo studies}

\section{Memantine ameliorated NMDA-mediated convulsions in mice and rats}

Pretreatment with memantine significantly ameliorated convulsions caused by the intracerebroventricular application of N-methyl-Daspartate in rats [26]. Similarly, memantine was administered to mice before systemic administration of $\mathrm{N}$-methyl-D-aspartate and was found to block N-methyl-D-aspartate-provoked convulsions in the pretreated mice when compared to that in the control mice [26, 27]. Prevention of $\mathrm{N}$-methyl-D-aspartate-mediated convulsions demonstrated the selective action of memantine on NMDA receptors.

\section{Neuroprotective effect of memantine}

The neuroprotective action of memantine has been demonstrated in many in vivo studies using cerebral ischemic animal models [28, 29]. In a mouse model of cerebral ischemia, pretreatment with memantine reduced the infarct size and acute excitotoxic cell damage, thus confirming its neuroprotective ability [30]. Interestingly, one study investigated whether memantine has a neuroprotective effect after the induction of brain damage. In this study, traumatic brain injury was induced in rats using specialized devices and followed by memantine treatment for 7 days. Memantine significantly reduced neuronal cell death and injury in the treated rats when compared to that in the control untreated rats [28]. In another study, memantine significantly upregulated brain-derived neurotrophic factor in the brains of treated rats in contrast to the control rats, thereby confirming its neuroprotective effect [31].

\section{Chronic neurodegenerative disease animal models}

The chronic administration of memantine in rats significantly protected them against hippocampal neuron damage induced by intracerebroventricular injection of quinolinic acid [32]. In another study, memantine significantly prevented striatal neuronal injury due to mitochondrial toxicity induced by the administration of malonate [33]. It is noteworthy that the use of malonate to induce mitochondrial toxicity is based on the notion that neurodegenerative diseases are associated with chronic excitotoxicity and the production of free radicals and mitochondrial toxicity. Another study investigated the effect of memantine in an animal model of neurodegeneration due to $\beta$-amyloidprovoked excitotoxicity; the neurodegenerative effects were significantly alleviated in memantine-treated rats when compared to that in vehicle-treated rats [34].

\section{Clinical studies on memantine}

The first randomized clinical trial investigating the efficacy and safety of memantine in patients with severe AD was conducted in the late 1990s [35]. A total of 166 patients were randomly divided to receive either $10 \mathrm{mg} /$ day of memantine $(n=82)$ or placebo $(\mathrm{n}=84)$ for 12 weeks. The memantine-treated group exhibited significant functional improvement and required less time for supportive care when compared to the placebo-treated group [35].

In a randomized placebo-controlled clinical trial, a total of 252 patients with moderate to severe $A D$ in more than 30 US centers were randomly assigned to receive a dose of $10 \mathrm{mg}$ memantine or placebo twice daily for 28 weeks [36]. At the end of 28 weeks, a significant improvement in clinical symptoms and functional activities was observed in the memantine-treated patients in contrast to that in the placebo-treated patients. Moreover, memantine was well-tolerated, and there were no signs or symptoms of any significant side effects in the treated patients [36].

The last clinical trial that was submitted to the FDA investigated the effect of combination therapy with a cholinesterase inhibitor (donepezil) and memantine [37]. This randomized, double-blind, placebo-controlled study was conducted in 322 patients with moderate to severe $A D$ who were already receiving donepezil. Patients from 37 US centers were randomly assigned to receive either 20 $\mathrm{mg} /$ day memantine or placebo for 24 weeks. The 
results of this trial were consistent with those of previous studies indicating the benefits of memantine over placebo treatment when added to donepezil [37]. It is noteworthy that one retrospective study to analyze three previous

Table 1: Examples of preclinical studies on memantine clinical trials focusing on $A D$ patients with agitation or aggression provided significant evidence that memantine is well-tolerated and effective for treating patients with moderate to severe AD [38].

\begin{tabular}{|c|c|c|c|}
\hline Study & Experiment/assay & Findings & Reference \\
\hline In vitro & $\begin{array}{l}\text { NMDA receptor antagonism } \\
\text { assay }\end{array}$ & $\begin{array}{l}\text { Memantine was found to antagonize the current that } \\
\text { was evoked by NMDA with a } 50 \% \text { inhibition } \\
\text { concentration of approximately } 1 \mathrm{uM}\end{array}$ & {$[22]$} \\
\hline In vitro & $\begin{array}{l}\text { NMDA-induced calcium influx } \\
\text { inhibition assay }\end{array}$ & $\begin{array}{l}\text { Memantine strongly inhibited excessive calcium } \\
\text { influx that was simulated by a high concentration of } \\
\text { NMDA. } \\
\text { Memantine allowed a low level of calcium influx } \\
\text { similar to that evoked by a low concentration of } \\
\text { NMDA }\end{array}$ & [21] \\
\hline In vitro & $\begin{array}{c}\text { NMDA receptor-mediated } \\
\text { neurotoxicity antagonism assay }\end{array}$ & $\begin{array}{l}\text { Memantine exhibited strong antagonism of the } \\
\text { neurotoxic effects mediated by NMDA receptors in } \\
\text { cortical neurons, rat retinal ganglion and cortical } \\
\text { neuron cell cultures }\end{array}$ & $\begin{array}{l}{[22,24,} \\
25]\end{array}$ \\
\hline In vivo & $\begin{array}{l}\text { NMDA-mediated convulsions } \\
\text { experiments }\end{array}$ & $\begin{array}{l}\text { Memantine was found to block NMDA-provoked } \\
\text { convulsions in rats and mice }\end{array}$ & {$[26,27]$} \\
\hline In vivo & Neuroprotection experiments & $\begin{array}{l}\text { Memantine reduced the infarct size and the acute } \\
\text { excitotoxic cell damage in cerebral ischemic model } \\
\text { Memantine induced neuroprotection by significantly } \\
\text { reducing neuronal cell death and injury in rats with } \\
\text { traumatic brain injury } \\
\text { Memantine significantly upregulated the brain- } \\
\text { derived neurotrophic factor in the brains of rats }\end{array}$ & $\begin{array}{l}{[28,30,} \\
31]\end{array}$ \\
\hline In vivo & $\begin{array}{l}\text { Chronic neurodegenerative } \\
\text { disease animal models }\end{array}$ & $\begin{array}{l}\text { Memantine significantly protected rats against } \\
\text { hippocampal and striatal neuronal damage induced } \\
\text { quinolinic acid and malonate } \\
\text { Memantine protected against the neurodegenerative } \\
\text { effects of } \beta \text {-amyloid-provoked excitotoxicity in rats }\end{array}$ & [32-34] \\
\hline
\end{tabular}

Table 2: Examples of completed clinical trials on memantine's efficacy and safety in AD

\begin{tabular}{llll}
\hline Reference & $\mathbf{N}$ & Treatment & Results \\
\hline [35] & 166 & $\begin{array}{l}\text { Memantine } \\
\text { Placebo }\end{array}$ & $\begin{array}{l}\text { The memantine-treated group exhibited a significant functional } \\
\text { improvement and required less time for supportive care } \\
\text { compared to the placebo-treated group }\end{array}$ \\
[36] & 252 & $\begin{array}{l}\text { Memantine } \\
\text { Placebo }\end{array}$ & $\begin{array}{l}\text { Significant improvement in clinical symptoms and functional } \\
\text { activities was observed in the memantine-treated patients as } \\
\text { compared to the placebo-treated patients } \\
\text { Memantine was well-tolerated, and there were no signs or } \\
\text { symptoms of any significant side effects in the treated patients }\end{array}$ \\
& 322 & $\begin{array}{l}\text { Memantine } \\
\text { Donepezil } \\
\text { Placebo }\end{array}$ & $\begin{array}{l}\text { Memantine showed significant improvements as compared to } \\
\text { placebo when added to donepezil in cognition and was well } \\
\text { tolerated }\end{array}$ \\
& Memantine & $\begin{array}{l}\text { Patients on cholinesterase inhibitors who were treated with } \\
\text { memantine showed earlier improvements in cognitive functions } \\
\text { as compared to placebo }\end{array}$ \\
\hline
\end{tabular}




\section{CONCLUDING REMARKS}

The exact molecular mechanisms underlying the interaction of memantine with NMDA receptors still need to be studied more to improve the efficacy and outcomes of this treatment strategy in the management of AD. Although clinical studies have demonstrated that memantine is effective for treating $A D$, it is not a cure. The limited curative effects of memantine could be attributable to the late administration of this drug when neuronal cell death has already started. Further studies are needed to investigate the early administration of this drug with other antioxidants that might improve its curative effect in $A D$.

\section{DECLARATIONS}

\section{Acknowledgement}

The author would like to thank $\operatorname{Dr}$ Ana Maria Hardy for help in editing this manuscript. The author also thanks Amal Alghorabi for the help in constructing the tables.

\section{Conflict of interest}

No conflict of interest is associated with this work.

\section{Contribution of authors}

We declare that this work was done by the authors named in this article and all liabilities pertaining to claims relating to the content of this article will be borne by the authors.

\section{Open Access}

This is an Open Access article that uses a funding model which does not charge readers or their institutions for access and distributed under the terms of the Creative Commons Attribution License (http://creativecommons.org/licenses/by/ 4.0) and the Budapest Open Access Initiative (http://www.budapestopenaccessinitiative.org/rea d), which permit unrestricted use, distribution, and reproduction in any medium, provided the original work is properly credited.

\section{REFERENCES}

1. Association A s. 2019 Alzheimer's disease facts and figures. Alzheimers Dement 2019; 15(3): 321-387.

2. Liu-Seifert $H$, Schumi J, Miao X, Tian Y, Rabbia M, Andersen $S$ W, Wilson S, Li W, Entsuah R. Disease
Modification in Alzheimer's Disease: Current Thinking. Ther Innov Regul Sci 2020; 54(2): 396-403.

3. Conway M E. Alzheimer's disease: targeting the glutamatergic system. Biogerontology 2020; 1-18.

4. Lipton $S A$. Failures and successes of NMDA receptor antagonists: molecular basis for the use of openchannel blockers like memantine in the treatment of acute and chronic neurologic insults. NeuroRx 2004; 1(1): 101-110.

5. Folch J, Busquets O, Ettcheto M, Sánchez-López E, Castro-Torres $R \quad D$, Verdaguer $E$, Garcia $M L$, Olloquequi J, Casadesús G, Beas-Zarate C. Memantine for the treatment of dementia: a review on its current and future applications. J Alzheimers Dis 2018; 62(3): 1223-1240.

6. Bowers $M S$, Cacheaux $L P$, Sahu $S U$, Schmidt $M E$, Sennello $J A$, Leaderbrand $K$, Khan $M A$, Kroes $R A$, Moskal J R. NYX-2925 induces metabotropic $N$-methyl-d-aspartate receptor (NMDAR) signaling that enhances synaptic NMDAR and $\alpha$-amino-3-hydroxy-5-methyl-4-isoxazolepropionic acid receptor. J Neurochem 2020; 152(5): 523-541.

7. Simões $A P$, Silva $C G$, Marques $J M$, Pochmann $D$, Porciúncula L O, Ferreira S, Oses J P, Beleza R O, Real $J$ I, Köfalvi A. Glutamate-induced and NMDA receptormediated neurodegeneration entails P2Y1 receptor activation. Cell Death Dis 2018; 9(3): 1-17.

8. Hardingham $G E$, Bading $H$. Synaptic versus extrasynaptic NMDA receptor signalling: implications for neurodegenerative disorders. Nat Rev Neurosci 2010; 11(10): 682-696.

9. McShane R, Westby $M J$, Roberts E, Minakaran $N$, Schneider L, Farrimond L E, Maayan N, Ware J, Debarros J. Memantine for dementia. Cochrane Database Syst Rev 2019; (3).

10. Hay A, Wolstenholme A, Skehel J, Smith MH. The molecular basis of the specific anti-influenza action of amantadine. EMBO J 1985; 4(11): 3021-3024.

11. Gandhi C S, Shuck $K$, Lear J D, Dieckmann $G R$, DeGrado W F, Lamb R A, Pinto L H. Cu (II) inhibition of the proton translocation machinery of the influenza $A$ virus M2 protein. J Biol Chem 1999; 274(9): 5474-5482.

12. Schneider E, Fischer $P$, Clemens R, Balzereit F, Fünfgeld $E$, Haase $H$. [Effects of oral memantine administration on Parkinson symptoms. Results of a placebo-controlled multicenter study]. Dtsch Med Wochenschr 1984; 109(25): 987-990.

13. Skuza G, Rogoz Z, Quack G, Danysz W. Memantine, amantadine, and L-deprenyl potentiate the action of $L$ dopa in monoamine-depleted rats. J Neural Transm Gen Sect 1994; 98(1): 57-67.

14. Gianutsos G, Chute S, Dunn J P. Pharmacological changes in dopaminergic systems induced by long-term administration of amantadine. Eur J Pharmacol 1985; 110(3): 357-361.

15. Borrmann J. Memantine is a potent blocker of N-methyld-aspartate (NMDA) receptor channel. Eur J Pharmacol 1989; 166(3): 591-592.

Trop J Pharm Res, July 2020; 19(7): 1539 
16. Müller W E, Mutschler E, Riederer $P$. Noncompetitive NMDA receptor antagonists with fast open-channel blocking kinetics and strong voltage-dependency as potential therapeutic agents for Alzheimer's dementia. Pharmacopsychiatry 1995; 28(4): 113-124.

17. Kabir M T, Sufian M A, Uddin M, Begum M, Akhter $S$, Islam A, Mathew B, Islam M, Amran M. NMDA Receptor Antagonists: Repositioning of Memantine as a Multitargeting Agent for Alzheimer's Therapy. Curr Pharm Des 2019; 25(33): 3506-3518.

18. Limapichat $W, Y u W Y$, Branigan E, Lester $H A$, Dougherty $D A$. Key binding interactions for memantine in the NMDA receptor. ACS Chem Neurosci 2013; 4(2): 255-260.

19. Facci L, Leon A, Skaper S. Excitatory amino acid neurotoxicity in cultured retinal neurons: Involvement of N-methyl-D-Aspartate (NMDA) and Non-NMDA receptors and effect of ganglioside GM1. J Neurosci Res 1990; 27(2): 202-210.

20. Sucher $N$ J, Aizenman E, Lipton $S$ A. N-methyl-Daspartate antagonists prevent kainate neurotoxicity in rat retinal ganglion cells in vitro. J Neurosci 1991; 11(4): 966-971.

21. Chen H, Pellegrini J, Aggarwal S, Lei S Z, Warach S, Jensen F E, Lipton $S$. Open-channel block of N-methyl$D$-aspartate (NMDA) responses by memantine: therapeutic advantage against NMDA receptor-mediated neurotoxicity. J Neurosci 1992; 12(11): 4427-4436.

22. Chen H, Lipton $S A$. Mechanism of memantine block of NMDA-activated channels in rat retinal ganglion cells: uncompetitive antagonism. J Physiol 1997; 499(Pt 1): 27-46.

23. Choi $D$ W, Koh J-Y, Peters S. Pharmacology of glutamate neurotoxicity in cortical cell culture: attenuation by NMDA antagonists. J Neurosci 1988; 8(1): 185-196.

24. Hahn J S, Aizenman E, Lipton S A. Central mammalian neurons normally resistant to glutamate toxicity are made sensitive by elevated extracellular $\mathrm{Ca}^{2+}$ : toxicity is blocked by the N-methyl-D-aspartate antagonist MK801. Proc Natl Acad Sci 1988; 85(17): 6556-6560.

25. Erdö S L, Schäfer M. Memantine is highly potent in protecting cortical cultures against excitotoxic cell death evoked by glutamate and N-methyl-D-aspartate. Eur J Pharmacol 1991; 198(2): 215-217.

26. Bisaga A, Krzascik $P$, Jankowska E, Palejko W, Kostowski W, Danysz W. Effect of glutamate receptor antagonists on N-methyl-D-aspartate-and (S)-a-amino3-hydroxy-5-methyl-4-isoxazolepropionic acid-induced convulsant effects in mice and rats. Eur J Pharmacol 1993; 242(3): 213-220.

27. Parsons C, Quack G, Bresink I, Baran L, Przegalinski E, Kostowski W, Krzascik P, Hartmann S, Danysz W. Comparison of the potency, kinetics and voltagedependency of a series of uncompetitive NMDA receptor antagonists $<i>$ in vitro $<i>$ with anticonvulsive and motor impairment activity< i> in vivo</i>. Neuropharmacology 1995; 34(10): 1239-1258.
28. Raghavendra Rao V L, Dogan A, Todd K G, Bowen K K, Dempsey $R J$. Neuroprotection by memantine, a noncompetitive NMDA receptor antagonist after traumatic brain injury in rats. Brain Res 2001; 911(1): 96-100.

29. Gu S X, Sonkar V K, Katare $P B$, Kumar R, Kruger W D, Arning E, Bottiglieri T, Lentz $S R$, Dayal S. Memantine Protects From Exacerbation of Ischemic Stroke and Blood Brain Barrier Disruption in Mild But Not Severe Hyperhomocysteinemia. J Am Heart Assoc 2020; 9(4): e013368.

30. Backhauß C, Karkoutly C, Welsch M, Krieglstein J. A mouse model of focal cerebral ischemia for screening neuroprotective drug effects. I Pharmacol Toxicol Methods 1992; 27(1): 27-32.

31. Marvanová M, Lakso M, Pirhonen J, Nawa H, Wong G, Castrén E. The neuroprotective agent memantine induces brain-derived neurotrophic factor and trkB receptor expression in rat brain. Mol Cell Neurosci 2001; 18(3): 247-258.

32. Keilhoff G, Wolf G. Memantine prevents quinolinic acidinduced hippocampal damage. Eur J Pharmacol 1992; 219(3): 451-454.

33. Schulz J, Matthews $R$, Henshaw $D$, Beal $M$. Neuroprotective strategies for treatment of lesions produced by mitochondrial toxins: implications for neurodegenerative diseases. Neuroscience 1996; 71(4): 1043-1048.

34. Miguel-Hidalgo J, Alvarez X, Cacabelos R, Quack G. Neuroprotection by memantine against neurodegeneration induced by $\beta$-amyloid. Brain Res 2002; 958(1): 210-221.

35. Winblad B, Poritis N. Memantine in severe dementia: results of the 9M-best study (benefit and efficacy in severely demented patients during treatment with memantine). Int J Geriatr Psychiatry 1999; 14(2): 135146.

36. Reisberg B, Doody R, Stöffler A, Schmitt F, Ferris S, Möbius $H$ J. Memantine in moderate-to-severe Alzheimer's disease. N Engl J Med 2003; 348(14): 13331341.

37. Tariot $P N$, Farlow $M R$, Grossberg $G T$, Graham $S M$, McDonald S, Gergel I, Group M S. Memantine treatment in patients with moderate to severe Alzheimer disease already receiving donepezil: a randomized controlled trial. Jama 2004; 291(3): 317-324.

38. Wilcock G K, Ballard C G, Cooper J A, Loft H. Memantine for agitation/aggression and psychosis in moderately severe to severe Alzheimer's disease: a pooled analysis of 3 studies. J Clin Psychiatry 2008; 69(3): 341-348.

39. Grossberg G T, Alva G, Hendrix S, Ellison N, Kane M C, Edwards J. Memantine ER Maintains Patient Response in Moderate to Severe Alzheimer's Disease: Post Hoc Analyses From a Randomized, Controlled, Clinical Trial of Patients Treated With Cholinesterase Inhibitors. Alzheimer Dis Assoc Disord 2018; 32(3): 173-178.

Trop J Pharm Res, July 2020; 19(7): 1540 